\title{
Pengaruh Model Pembelajaran Example Non Example terhadap Hasil Belajar IPS
}

\author{
Rai Suadnyana Wijaya1* ${ }^{*}$ I Wayan Darsana², I Gusti Agung Oka Negara³
}

1 Jurusan PGSD Universitas Pendidikan Ganesha Singaraja, Indonesia

${ }^{2}$ Jurusan PGSD Universitas Pendidikan Ganesha Singaraja, Indonesia

3 Jurusan PGSD Universitas Pendidikan Ganesha Singaraja, Indonesia

\begin{abstract}
Abstrak
Penelitian ini bertujuan untuk megetahui perbedaan yang signifikan kompetensi pengetahuan IPS antara kelompok siswa yang dibelajarkan melalui model pembelajaran Example Non Example dengan kelompok siswa yang dibelajarkan dengan pembelajaran konvensional pada siswa kelas IV SD Gugus II Kuta Utara. Jenis penelitian ini merupakan eksperimen semu dengan menggunakan desain penelitian non-equivalent control group design. Sampel ditentukan dengan rumus random sampling dengan mengacak kelas yang terlebih dahulu dilakukan uji kesetaraan pada setiap anggota populasi. Sampel dalam penelitian ini adalah kelas IV SD No. 2 Tibubeneng sebagai kelompok eksperimen dan kelas IV SD No. 3 Tibubeneng sebagai kelompok kontrol, dengan jumlah masing - masing kelompok sebanyak 32 siswa pada kelompok eksperimen dan 32 siswa pada kelompok kontrol. Hasil Data kompetensi pengetahuan IPS dikumpulkan dengan instrumen tes objektif pilihan ganda berjumlah 30 butir tes yang telah divalidasi data di analis dengan Uji-t. Analisis menunjukkan terdapat perbedaan yang signifikan kompetensi pengetahuan IPS antara kelompok siswa yang dibelajarkan melalui model pembelajaran Example Non Example dengan kelompok siswa yang dibelajarkan melalui pembelajaran konvensional pada kelas IV SD Gugus II Kuta Utara hal tersebut dibuktikan dengan hasil thitung 3,23> ttabel $=2,00$. Rata - rata kompetensi pengetahuan IPA siswa kelompok eksperimen 69,09 > 67,27 kelompok kontrol. Dapat disimpulkan model pembelajaran Example Non Example berpengaruh terhadap kompetensi pengetahuan IPS siswa kelas IV SD Gugus II Kuta Utara.
\end{abstract}

\author{
Keywords: \\ model example non \\ example, hasil belajar \\ IPS
}

\section{PENDAHULUAN}

Pendidikan merupakan suatu faktor penting dalam kehidupan. Pendidikan adalah "suatu proses dalam rangka mempengaruhi peserta didik supaya mampu menyesuaikan diri sebaik mungkin dengan lingkungannya, dan dengan demikian akan menimbulkan perubahan dalam dirinya yang memungkinkannya untuk berfungsi secara adekwat dalam kehidupan masyarakat" (Hamalik, 2009:3). Pendidikan akan menunjang kualitas dari SDM yang dapat bersaing pada era globalisasi (Wardika, 2014). SDM yang berkualitas tidak serta merta mutlak diwariskan secara herediter, melainkan melalui suatu proses pembentukan yang sangat panjang melalui proses belajar. Terjadinya proses belajar yang baik, ditentukan oleh beberapa faktor yaitu, tenaga pendidik, anak didik, serta sarana-prasarana yang memadai. Tanpa adanya unsure-unsur tersebut, maka aoutput yang dihasilakn juga akan angat kurang. Salah satu faktor penting agara tercapainya SDM yang berkulitas adalh adanya guru yang professional (Ariani, 2017). Pengajaran bertugas mengarahkan proses ini agar sasaran dari perubahan itu dapat tercapai sebagaimana yang diinginkan.

Sekolah sebagai suatu lembaga pendidikan formal, secara sistematis merencanakan bermacammacam lingkungan, yakni lingkungan pendidikan yang menyediakan berbagai kesempatan bagi peserta didik untuk melakukan berbagai kegiatan belajar. Dengan berbagai kesempatan belajar itu, pertumbuhan dan perkembangan peserta didik diarahkan dan didorong ke pencapaian tujuan yang dicita-citakan. Lingkungan tersebut di susun dan ditata dalam suatu kurikulum, yang pada gilirannya dilaksanakan dalam bentuk proses pembelajaran. 
Tujuan pendidikan adalah seperangkat hasil pendidikan yang tercapai oleh peserta didik setelah diselenggarakannya kegiatan pendidikan. Seluruh kegiatan pendidikan, yakni bimbingan pengajaran, dan atau latihan diarahkan untuk mencapai tujuan pendidikan. Dalam konteks ini, tujuan pendidikan merupakan suatu komponen sistem pendidikan yang menempati kedudukan dan fungsi sentral. Itu sebabnya, setiap tenaga kependidikan perlu memahami dengan baik tujuan pendidikan, supaya berupaya melaksanakan tugas dan fungsinya untuk mencapai tujuan pendidikan yang telah ditentukan.

Pendidikan adalah" salah satu bentuk perwujudan kebudayaan manusia yang dinamis dan sarat perkembangan" (Trianto, 2009:1). Oleh karena itu, perubahan atau perkembangan pendidikan adalah hal yang memang seharusnya terjadi sejalan dengan perubahan budaya kehidupan. Perubahan dalam arti perbaikan pendidikan pada semua tingkat perlu terus-menerus dilakukan sebagai antisipasi kepentingan masa depan.

Pendidikan yang mampu mendukung pembangunan dimasa mendatang adalah pendidikan yang mampu mengembangkan potensi peserta didik, sehingga yang bersangkutan mampu menghadapi dan memecahkan problema kehidupan yang dihadapinya. Pendidikan harus menyentuh potensi nurani maupun potensi kompetensi peserta didik. Kompetensi pendidikan tersebut terasa semakin penting ketika seseorang harus memasuki kehidupan di masyarakat dan dunia kerja, karena yang bersangkutan harus mampu menerapkan apa yang dipelajari di sekolah untuk menghadapi permasalahan yang dihadapi dalam kehidupan sehari-hari saat ini maupun yang akan datang.

Undang-Undang Nomor 20 Tahun 2003 tentang Sistem Pendidikan Nasional menyebutkan bahwa kurikulum adalah seperangkat rencana dan pengaturan mengenai tujuan, isi, dan bahan pelajaran serta cara yang digunakan sebagai pedoman penyelenggaraan kegiatan pembelajaran untuk mencapai tujuan pendidikan tertentu.Kurikulum 2013 bertujuan untuk mempersiapkan manusia Indonesia agar memiliki kemampuan hidup sebagai pribadi dan warga negara yang beriman, produktif, kreatif, inovatif, dan afektif serta mampu berkontribusi pada kehidupan bermasyarakat, berbangsa, bernegara, dan peradaban dunia menurut Permendikbud No 57 Tahun 2014 Lampiran I. Kurikulum 2013 memberikan kesempatan kepada siswa untuk mengembangkan perbedaan dalam kemampuan dan minatnya. Siswa merupakan fokus utama di dalam proses pembelajaran, Melalui 5M, 1)Mengamati: mengamati obyek belajar secara bermakna. 2)Menanya: kemampuan bertanya yang baik. 3)Mencoba: memberikan kesempatan untuk mencoba, melakukan atau mengalami. 4)Menalar: memproses informasi yang sudah dikumpulkan. 5)Mengkomunikasikan : mempresentasikan atau menunjukkan hasil pekerjaan secara lisan atau tulisan atau bentuk karya lain sehingga mendapat respon yang lebih luas. Oleh karena itu, materi-materinya pun harus membantu siswa dalam mengembangkan kemampuan belajar, menyadari dan mensyukuri potensipotensi dirinya, berani menghadapi permasalahan kehidupan, serta memecahkannya secara kreatif. Penyusunan materi pelajaran harus menyesuaikan dengan paradigma pengajaran yang dikehendaki kurikulum 2013, yakni ditandai dengan pengembangan kompetensi berupa sikap, pengetahuan, keterampilan berpikir, dan keterampilan psikomotorik yang dikemas dalam berbagai macam pelajaran. Kurikulum dikembangkan dengan memberikan kesempatan kepada siswa untuk mengembangkan perbedaan dalam kemampuan dan minat. Selain itu, kurikulum 2013 berpusat pada potensi, perkembangan, kebutuhan, kepentingan siswa dan lingkungannya. Namun kenyataannya penerapan kurikulum 2013 dilapangan belum terlaksana dengan baik. Hal tersebut dikarenakan kurangnya penggunaan model/metode pembelajaran yang bervariasi serta kurang membuat siswa aktif dalam pembelajaran.

Berdasarkan observasi tanggal 20 Januari 2017 dengan guru kelas IV di SD Gugus II Kuta Utara, yang terdiri dari enam sekolah dasar dan sembilan kelas. Dalam proses pembelajaran terutama pada muatan materi pengetahuan IPS masih banyak di temukan permasalahan-permasalahan pada saat proses pembelajaran. Dilihat dari nilai raport semester 1 , salah satu permasalahan yang di temukan adalah masih banyaknya nilai hasil belajar IPS siswa yang berada di bawah kriteria ketuntasan minimal (KKM). Berdasarkan hal tersebut menurut guru kelas IV di SD gugus II Kuta Utara hal tersebut disebabkan karena guru menerapkan pembelajaran hanya menggunakan buku pegangan sehingga siswa kurang aktif dan kreatif serta membuat siswa kurang termotivasi terhadap pembelajaran. Proses belajar mengajar di kelas perlu dikemas secara aktif, kreatif dan inovatif. Salah satu inovasi yang dimaksud yakni dengan menerapkan model Example non example.

Example non example merupakan setrategi pembelajaran yang menggunakan gambar sebagai media untuk menyampaikan materi pelajaran"(Huda, 2015:234). Strategi ini bertujuan mendorong siswa untuk belajar berpikir kritis dengan memecahkan permasalahan-permasalahan yang termuat dalam contoh-contoh gambar yang disajikan. Penggunaan media gambar dirancang agar siswa dapat menganalisis gambar tersebut untuk kemudian dideskripsikan secara singkat perihal isi dari sebuah gambar. Dengan demikian, setrategi ini menekankan pada konteks analisis siswa. Gambar yang digunakan dalam strategi ini dapat ditampilkan melalui proyektor, atau yang paling sederhana, yaitu poster. Gambar 
ini haruslah jelas terlihat meski dari jarak jauh, sehingga siswa yang berada di bangku belakang dapat juga melihatnya dengan jelas. Berdasarkan uraian tersebut, secara teoritis model example non example berpengaruh terhadap hasil belajar IPS yang berjudul tetapi secara empiris perlu dibuktikan dengan penelitian ang berjudul "Pengaruh model pembelajaran example non example terhadap hasil belajar IPS siswa kelas IV Sekolah Dasar Gugus II Kuta Utara Tahun ajaran 2016/2017".

Berdasarkan latar belakang yang telah diuraikan tersebut, dapat diidentifikasi masalah - masalah yang ditemui di SD sebagai berikut : 1)Lemahnya hasil Hasil belajar IPS pada siswa kelas IV; 2)Kurangnya inovasi - inovasi guru dalam menggunakan model pembelajaran; 3)Penyampaian materi pembelajaran masih menggunakan ceramah tanpa menggunakan media pembelajaran; 4)Sulitnya siswa memahami materi pembelajaran karena hanya melalui mendengar dan membaca tanpa mengetahui bagaimana bentuknya.

Adapun tujuan dari penelitian ini adalah : 1) Untuk mengetahui hasil belajar IPS yang dibelajarkan melalui model example non example pada siswa kelas IV SD Gugus II Kuta Utara tahun pelajaran 2016/2017. 2)Untuk mengetahui hasil belajar IPS yang dibelajarkan melalui pembelajaran konvensional pada siswa kelas IV SD Gugus II Kuta Utara tahun pelajaran 2016/2017. 3)Untuk mengetahui perbedaan yang signifikan hasil belajar IPS kelompok siswa yang dibelajarkan melalui model example non example dengan kelompok siswa yang dibelajarkan melalui pembelajaran konvensional pada siswa kelas IV SD Gugus II Kuta Utara tahun pelajaran 2016/2017.

\section{METODE PENELITIAN}

Penelitian ini dilaksanakan pada semester 2 tahun pelajaran 2016/2017 di kelas IV A SD Gugus II Kuta Utara. Populasi dari penelitian ini adalah seluruh siswa kelas IV (empat) SD Gugus II Kuta Utara tahun pelajaran 2016/2017, yang terdiri dari 9 kelas dalam 6 sekolah dasar. Jumlah populasi dari penelitian ini adalah 278 orang, Sample yang digunakan mengunakan teknik random sampling dengan cara diundi dengan hasil sample kelas IV A SD No. 2 Tibubeneng berjumlah 33 siswa muncul pertama dan dijadikan kelas eksperimen dan kelas IVA SD No. 3 Tibubeneng yang berjumlah 33 siswa muncul kedua dan dijadikan sebagai kelas control. Pada kelas eksperimen diberikan perlakuan berupa model pembeljaran example non example dan pada kelas kontrol diberikan perlakuan berupa model pembelajaran konvensional. .

Jenis penelitian yang dilakukan dalam penelitian ini adalah penelitian kuantitatif dengan desain eksperimental yaitu quasi eksperiment (Eksperimen Semu). Desain ini memiliki kelompok kontrol, tetapi tidak bisa sepenuhnya mengontrol variabel-variabel luar yang mempengaruhi pelaksanaan eksperimen. Hal ini dikarenakan kemampuan peneliti dalam mengamati perilaku siswa sangat terbatas terutama ketika siswa berada di luar sekolah (rumah), peneliti juga tidak memiliki kemampuan untuk mengetahui persepsi siswa terhadap perlakuan secara pasti. Desain eksperimen yang digunakan adalah "Nonequivalent control group design".

Pada desain ini, baik kelompok eksperimental maupun kelompok kontrol dibandingkan. Pre Test diberikan untuk kelompok kontrol dan kelompok eksperimen. Setelah itu peneliti memberikan perlakuan, yaitu dengan memberikan model example non example kepada kelompok eksperimen dan memberikan pembelajaran konvensional kepada kelompok kontrol. Kemudian setelah diberikan perlakuan, dilakukan post tes untuk mengetahui hasil belajar IPS.

Langkah-langkah yang dilakukan pada tahap akhir penelitian adalah pada tahap akhir eksperiman, kegiatan yang akan dilakukan adalah memberikan post-test pada akhir penelitian untuk mengetahui hasil belajar siswa pada masing- masing kelas baik kelas exsperimen maupun kelas kontrol. Instrumen yang digunakan untuk mengumpulkan data tentang hasil belajar IPS adalah tes. Jenis tes yang digunakan dalam penelitian ini adalah bentuk tes pilihan ganda (Multiple Choise Test). Menurut Suharsimi (2013:183) menyatakan bahwa Multiple Choise Test terdiri atas suatu keterangan atau pemberitahuan tentang suatu pengertian yang belum lengkap. Untuk melengkapinya harus dipilih satu dari beberapa kemungkinan jawaban yang telah disediakan. Atau tes pilihan ganda terdiri atas bagian keterangan (stem) dan bagian kemungkian jawaban atau alternaif (option). Kemungkinan jawaban (option) terdiri atas satu jawaban yang benar yaitu kunci jawaban dan beberapa pengecoh (distractor). Tes yang digunakan untuk mengambil data terdiri dari 40 butir soal tes pilihan ganda. Sebelum digunakan, tes tersebut terlebih dahulu divalidasi secara teoritis dengan menggunakan kisi-kisi dan dikonsultasikan pada ahli, selanjutnya dilakukan validitas secara empiris dengan jumlah 40 responden dari siswa kelas $V$ di SD No, 2 Tibubeneng, sehingga $r_{-}$(tabel ) pada taraf signifikansi $5 \%$ adalah 0,334 . Untuk mengetahui validitas tes hasil belajar IPS, semua komponen dalam menentukan koefisien butir soal pilihan ganda biasa yang digunakan adalah dengan bantuan program aplikasi Microsoft Excel. Dari hasil uji validitas butir yang dilakukan, diperoleh 30 butir tes yang valid dan 10 butir tes tidak valid. Jadi terdapat 30 butir tes yang 
digunakan untuk tes hasil belajar IPS siswa kelas IV SD N 2 Tibubeneng.. Dari hasil uji instrument yang meliputi uji validitas, reliabilitas, uji daya beda dan uji indeks kesukaran diperoleh 20 butir tes yang dinyatakan layak digunakan dalam penelitian dari total 40 butir tes yang diujicobakan.

Teknik yang digunakan untuk menganalisis hasil belajar IPS dalam penelitian ini adalah dengan menggunakan analisis statistic yaitu uji-t. Sebelum dilaksanakannya uji prasyarat yang meliputi uji normalitas dan uji homogenitas varians.

\section{ANALISIS DAN PEMBAHASAN}

Hipotesis penelitian yang diuji adalah $\mathrm{H}_{0}$ yang berbunyi tidak terdapat perbedaan yang signifikan hasil belajar IPS antara kelompok siswa yang dibelajarkan menggunakan model pembelajaran Example non example dan kelompok siswa yang dibelajarkan menggunakan model pembelajaran konvensional pada siswa kelas IV SD Gugus Kuta Utara Tahun Pelajaran 2016/2017. Berdasarkan hasil uji normalitas dan uji homogenitas varians diperoleh data kedua kelompok yaitu kelompok siswa yang dibelajarkan menggunakan model pembelajaran Example non example dan kelompok siswa yang dibelajarkan menggunakan model pembelajaran konvensional berdistribusi normal dan varian kedua kelompok homogen. Berdasarkan hal itu maka uji statistik yang digunakan dalam penelitian ini adalah uji beda mean (uji-t) dengan rumus polled varians. Dengan kriteria pengujian jika $t_{\text {hitung }}<\mathrm{t}_{\text {tabel }}$, maka $\mathrm{H}_{0}$ diterima dan $\mathrm{H}_{\mathrm{a}}$ ditolak, dan jika harga $t_{\text {hitung }}>t_{\text {tabel }}$, maka $\mathrm{H}_{0}$ ditolak dan ha diterima. Pada taraf signifikansi $5 \% \quad(\alpha=$ $0,05)$ dengan $\mathrm{dk}=\mathrm{n}_{1}+\mathrm{n}_{2}-2$. Hasil perhitungan uji hipotesis disajikan dalam Tabel 1 .

Tabel 1. Tabel Uji Hipotesis

\begin{tabular}{llllllll}
\hline Sampel & $\mathbf{N}$ & $\mathbf{D k}$ & Mean & Varians & $\mathbf{t}_{\text {hit }}$ & $\mathbf{t}_{\text {tabel }}$ & Kesimpulan \\
\hline $\begin{array}{l}\text { Kelompok } \\
\text { Eksperimen }\end{array}$ & 32 & 64 & 69,09 & $\mathbf{1 4 3 , 2 1}$ & & & \\
$\quad \begin{array}{l}\text { Kelompok } \\
\text { Kontrol }\end{array}$ & 32 & & 67,27 & 143,92 & & 2,00 & $\mathrm{H}_{\text {a diterima }}$ \\
\hline
\end{tabular}

Berdasarkan table sebelumnya, dapat dilihat bahwa $t_{\text {hitung }}$ lebih besar dari pada $t_{\text {tabel }}$ yaitu 3,23 $>2,00$. Dengan hasil tersebut maka dapat disimpulkan bahwa $\mathrm{H}_{0}$ yang berbunyi "tidak terdapat perbedaan yang signifikan hasil belajar IPS antara kelompok siswa yang dibelajarkan menggunakan model pembelajaran Example non example dan kelompok siswa yang dibelajarkan menggunakan model pembelajaran konvensional pada siswa kelas IV SD Gugus II Kuta Utara Tahun Pelajaran 2016/2017", ditolak dan $\mathrm{H}_{\mathrm{a}}$ yang menyatakan "terdapat perbedaan yang signifikan hasil belajar IPS antara kelompok siswa yang dibelajarkan menggunakan model pembelajaran Example non example dan kelompok siswa yang dibelajarkan menggunakan model pembelajaran konvensional pada siswa kelas IV SD Gugus Kuta Utara Tahun Pelajaran 2016/2017 diterima.

Pembelajaran tematik tema 7 muatan IPS pada kelompok yang dibelajarkan melalui model pembelajaran Example non example berjalan dengan baik dan kondusif. Hal ini disebabkan oleh model pembelajaran Example non example merupakan pembelajaran kelompok menggunakan sistem kerja kelompok dengan kelipatan empat, dimana dua siswa bertamu ke kelompok lain dan dua siswa lainnya tetap di kelompoknya untuk menerima dua orang lain yang akan meminta informasi ataupun diberikan informasi. Suatu inovasi pembelajaran yang mendorong siswa aktif dalam kegiatan berdiskusi secara berkelompok yang terdiri dari kelompok heterogen dengan memanfaatkan media audio visual dalam proses untuk menunjang kegiatan pembelajaran agar berjalan secara optimal. Selama kegiatan pembelajaran siswa diajak untuk bekerja sama dalam menemukan suatu konsep. Penggunaan model pembelajaran Example non example mengarahkan siswa untuk aktif, baik dalam berdiskusi, tanya jawab, mencari jawaban, menjelaskan dan juga menyimak materi yang dijelaskan oleh teman. Dimana kelompok dibentuk dari siswa yang memiliki kemampuan tinggi, sedang dan rendah. Dengan suasana kelas yang demokratis, yang saling membelajarkan siswa yang mempunyai pengetahuan lebih, sedang dan kurang saling berbaur dan saling mengisi satu dengan yang lainnya. Hal ini disebabkan siswa yang kurang mampu mengaitkan antar materi pada muatan materi IPS dan kesulitan mengikuti setiap langkah pembelajaran yang perlu diberikan bimbingan lebih khusus. Pembelajaran menggunakan model pembelajaran pembelajaran Example non example pada muatan materi IPS memberikan kesempatan yang lebih luas kepada siswa untuk mengonstruksikan pengetahuannya melalui berbagai kegiatan bermakna dan teratur yang tentunya menyenangkan bagi siswa pada setiap langkah pembelajarannya. 
Dengan demikian, pembelajaran menggunakan model pembelajaran pembelajaran Example non example pada penelitian ini memiliki keunggulan, yaitu pembelajaran yang melatih kerjasama, pemahaman antar siswa sehingga mereka lebih aktif dalam belajar dan dapat memberikan kebermaknaan dalam proses pembelajaran. Model pembelajaran ini menekankan pada proses pembelajaran yang memberikan kesempatan kepada siswa untuk mendapatkan pengalaman secara langsung dan bermakna dalam mengembangkan pola berpikirnya (penalarannya). Selain itu, sistem pembelajaran berkelompok memiliki tujuan agar siswa dapat saling bekerja sama, bertanggung jawab, saling membantu memecahkan masalah, dan saling mendorong satu sama lain untuk berprestasi serta melatih siswa untuk bersosialisasi dengan baik.

Berdasarkan uji hipotesis diperoleh $t_{\text {hitung }}=3,23$ sedangkan pada taraf signifikansi $5 \%$ dan dk $=64$ diperoleh nilai $t_{\text {tabel }}=2,00$ sehingga $t_{\text {hitnung }}=3,23>t_{\text {tabel }}=2,00$. Dengan demikian, hipotesis nol (Ho) ditolak. Hal ini berarti terdapat perbedaan yang signifikan antara kelompok siswa yang dibelajarkan menggunakan model pembelajaran example non example dan kelompok siswa yang dibelajarkan menggunakan model pembelajaran konvensional pada siswa kelas IV di SD Gugus II Kuta Utara Tahun Pelajaran 2016/2017. Perolehan hasil perhitungan analisis data yang dilakukan menunjukkan bahwa nilai rata-rata siswa yang mengikuti pembelajaran menggunakan model pembelajaran example non example $(\bar{X}=\mathbf{6 9 , 0 9})$ dan siswa yang mengikuti pembelajaran konvensional $(\bar{X}=\mathbf{6 7 , 2 7})$.

Dengan demikian, terdapat pengaruh hasil belajar IPS antara siswa kelas IV di SD Gugus II Kuta Utara Tahun Pelajaran 2016/2017 yang mengikuti pembelajaran dengan menggunakan model pembelajaran example non example dan siswa yang mengikuti pembelajaran konvensional pada tema 7 (Hal ini mendukung hipotesis yang menyatakan bahwa terdapat perbedaan yang signifikan antara kelompok siswa yang dibelajarkan menggunakan model pembelajaran example non example dan kelompok siswa yang dibelajarkan menggunakan model pembelajaran konvensional pada siswa kelas IV di SD Gugus II Kuta Utara Tahun Pelajaran 2016/2017, penelitian ini sejalan dengan penelitian Dewi (2017) yang menunjukkan bahwa penerapan model pembelajaran Examples Non-Examples berbasis lingkungan berpengaruh terhadap hasil belajar IPA siswa kelas V SD Negeri Gugus Kapten Japa Denpasar Utara, penelitian oleh Mirnawati (2014) menunjukkan bahwa model pembelajaran examples non examples berpengaruh tidak signifikan terhadap hasil belajar kognitif siswa dan berpengaruh terhadap sikap peduli lingkungan oleh siswa.

\section{KESIMPULAN}

Hasil belajar siswa pada mata pelajaran IPS SD Negeri di Gugus II Kuta Utara belum maksimal dipahami oleh siswa. Banyak faktor yang mempengaruhi hal tersebut diantaranya adalah kurangnya minat belajar siswa, kurang memanfaatkan sumber dan fasilitas belajar yang dimiliki sekolah dan lingkungan yang secara tidak langsung mempengaruhi siswa tersebut. Hal ini terbukti dari hasil wawancara dengan kepala sekolah dan guru wali kelas IV SD Negeri Gugus II Kuta Utara.

Sebagai salah satu alternatif untuk mengatasi kelemahan-kelemahan yang dihadapi guru di lapangan, peneliti menerapkan strategi pembelajaran untuk mengoptimalkan proses pembelajaran terhadap kompetesi pengetahuan IPS siswa. Strategi tersebut adalah model pembelajaran example non example Model pembelajaran example non example adalah model pembelajaran dengan proses bertukar pasangan dengan pasangan lainnya dan nantinya harus kembali ke pasangan semula dengan bantuan unsur gambar bergerak dan suara yang memanfaatkan indera pendengaran dan pengelihatan memudahkan untuk membagikan hasil dan informasi dengan kelompok lain.

Berdasarkan permasalahan tersebut penelitian ini bertujuan untuk mengetahui perbedaan yang signifikan terhadap hasil belajar IPS siswa yang dibelajarkan dengan menggunakan model example non example dan kelompok siswa yang dibelajarkan dengan menggunakan model pembelajaran konvensional pada siswa kelas IV SD Negeri Gugus Kuta Utara Tahun Pelajaran 2016/2017. Dan penelitian ini bermanfaat untuk pengembanagan teori-teori pendidikan dan strategi pembelajaran terutama yang berkaitan dengan model pembelajaran example non example serta hasil belajar IPS yang membuat siswa menjadi aktif dan senang dalam proses pembelajaran.

Penelitian ini merupakan penelitian kuantitatif dengan jenis penelitian yaitu eksperimen semu (Quasi Eksperiment) yang dilaksanakan di kelas V Gugus Kompyang Sujana Denpasar Utara. Desain yang digunakan yaitu "Nonequivalent Control Group Design". Dalam desain ini terdapat dua kelompok, yaitu kelompok eksperimen dan kelompok kontrol. Pelaksanaan penelitian ini terdiri dari 3 tahapan yaitu, (1) tahap persiapan, (2) tahap pelaksanaan, (3) tahap eksperimen (tahap akhir eksperimen).

Populasi penelitian ini adalah seluruh siswa kelas IV SD Negeri Gugus II Kuta Utara yang terdiri dari 6 SD yang keseluruhannya berjumlah 278 siswa. Dari populasi yang yang telah ditentukan maka selanjutnya diambil perwakilan dari populasi tersebut yang dianggap mewakili seluruh populasi disebut 
sampel. Dalam penelitian ini sampel yang dipilih adalah dua kelas, yaitu satu kelas eksperimen dan satu kelas kontrol, kedua kelas tersebut nantinya akan diberikan perlakuan yang berbeda. Satu kelas akan diberikan perlakuan dengan model pembelajaran example non exampel dan satu kelas lagi diberikan perlakuan menggunakan pembelajaran konvensional. Pengambilan sampel dalam penelitian ini menggunakan teknik Random Sampling.

Untuk menentukan sampel, seluruh kelompok dalam populasi yaitu siswa kelas IV di SD Gugus Gugus II Kuta Utara diberikan pre test. Hasil dari pre test diuji analisis dengan uji beda rerata antar kelompok kelas. Selanjutnya akan diuji kesetaraan sampel menggunakan uji-t dengan rumus Polled Varians. Sebelum dilakukan uji kesetaraan kelas dari seluruh anggota populasi dengan uji-t, terlebih dahulu dilakukan uji prasyarat analisis yakni dengan melakukan uji normalitas dan uji homogenitas. Tahap selanjutnya, setelah didapat kelas-kelas anggota dari populasi yang setara, maka dilakukan pengundian untuk menentukan dua kelas yang dijadikan sebagai sampel penelitian. Kemudian, dilakukan pengundian kembali terhadap kedua kelas sampel yang terpilih untuk menentukan kelas yang menjadi kelompok eksperimen dan kelas yang menjadi kelompok kontrol. Setelah dilakukan pengundian, kelas IV A SD N 2 Tibubeneng menjadi kelompok eksperimen dan kelas IV SD N 3 tibubeneng menjadi kelompok kontrol.

Berdasarkan penelitian yang telah dilaksanakan maka dapat ditarik simpulan sebagai berikut: 1)Hasil belajar IPS siswa yang dibelajarkan melalui model pembelajaran example non exampel pada siswa kelompok eksperimen sebesar 69,09 dengan nilai tertinggi yang diperoleh siswa adalah 90 dan nilai terendah 50.2) Hasil belajar IPS siswa yang dibelajarkan melalui pembelajaran konvensional pada siswa kelompok kontrol sebesar 67,27 dengan nilai tertinggi yang diperoleh siswa adalah 85 dan nilai terendah 40. 3) Rerata hasil belajar IPS yang diperoleh siswa yang dibelajarkan melalui model pembelajaran example non exampel lebih tinggi dari siswa yang dibelajarkan melalui pembelajaran konvensional $(69,09>67,27)$. Berdasarkan hasil analisis dengan menggunakan uji-t dengan $\mathrm{dk}=64 \mathrm{pada}$ taraf signifikansi 5\% diperoleh thitung $=3,23>$ ttabel $=2,00$ ini berarti bahwa terdapat perbedaan yang signifikan hasil belajar IPS antara kelompok siswa yang dibelajarkan menggunakan model pembelajaran example non exampel dan kelompok siswa yang dibelajarkan menggunakan model pembelajaran konvensional pada siswa kelas IV (empat) SD Gugus II Kuta Utara Tahun Pelajaran 2016/2017 pada tema 7 . Hal tersebut menyatakan bahwa terdapat pengaruh model pembelajaran example non exampel terhadap hasil belajar IPS siswa kelas V SD Gugus II Kuta Utara Tahun Tahun Pelajaran 2016/2017.

Berdasarkan hasil penelitian, pembahasan dan simpulan, maka dapat diajukan beberapa saran kepada beberapa pihak sebagai berikut: 1)Bagi guru, penelitian ini bisa dijadikan acuan untuk meningkatkan keterampilan dalam merancang pembelajaran dengan tujuan memperoleh hasil belajar yang optimal. Khususnya guru yang mengajar di kelas IV yang menggunakan tematik disarankan untuk mengembangkan inovasi pembelajaran dengan menerapkan strategi, pendekatan, model, dan metode yang mampu mengoptimalkan hasil belajar siswa. Dengan pendekatan saintifik menggunakan pertanyaan jawaban tertunda menjadi salah satu pendekatan yang dikombinasikan dengan karakteristik pertanyaan guru yang dapat diterapkan dalam proses pembelajaran. 2) Bagi siswa, dengan diterapkannya model pembelajaran example non exampel pada muatan IPS, diharapkan siswa untuk aktif dan mengeluarkan ide-ide dari pemikiran kritis siswa untuk membangun pengetahuannya sendiri. Dengan demikian siswa menjadi kreatif dan mandiri dalam mengikuti pembelajaran. 3) Bagi sekolah, penelitian ini menunjukkan bahwa hasil belajar siswa yang dibelajarkan dengan model pembelajaran example non example lebih tinggi dari pada hasil belajar siswa yang dibelajarkan dengan pembelajaran konvensional. Diharapkan sekolah memberikan sosialisasi secara berkelanjutan mengenai inovasi-inovasi pembelajaran kepada guru dalam membelajarkan siswa. 4) Bagi peneliti lainnya, bahwa dalam penelitian ini terbatas pada pokok bahasan tematik tema 7 siswa kelas IV. Untuk memperoleh kompetensi yang berbeda dan pada mata pelajaran yang berbeda peneliti menyarankan kepada peneliti lainnya untuk melakukan penelitian pada pokok bahasan yang lebih beragam untuk memperoleh hasil yang lebih baik

\section{DAFTAR PUSTAKA}

Abidin, Yusuf. 2014. "Desain Sistem Pembelajaran Dalam Konteks Kurikulum 2013". Refika Aditama: Bandung.

Ahmad, Susanto. 2013. Teori Belajar dan Pembelajaran di Sekolah Dasar. Jakarta: Kencana Prenada Media Group.

Agung, A.A. Gede. 2014. Metodologi Penelitian Pendidikan. Singaraja : Aditya Media Publising. 
Arikunto, Suharsimi. 2013. Dasar-Dasar Evaluasi Pendidikan. Jakarta: Bumi Aksara.

2015. Dasar-Dasar Evaluasi Pendidikan. Jakarta: Bumi Aksara.

Ariani, Kadek Dwi Dharma, Luh Putu Putrini Mahadewi, Ni Wayan Rati. 2017. Pengaruh Model Pembelajaran Examples Non Examples Terhadap Hasil Belajar Ipa Siswa Kelas V SD. e-Journal PGSD Universitas Pendidikan Ganesha Mimbar PGSD Vol. 5 No. 2.

Candiasa, I, M. 2010. Statistik Univariat dan Bivariat Disertai Aplikasi SPSS. Singaraja: Unit Penerbitan Universitas Pendidikan Ganesha.

Dewi, Ni Nyoman Purna ,I Gst. Agung Oka Negara, I Nengah Suadnyana. Model Pembelajaran Examples Non-Examples Berbasis Lingkungan Berpengaruh Terhadap Hasil Belajar Ipa Siswa Kelas V Sd Negeri Gugus Kapten Japa . e-Journal MIMBAR PGSD Universitas Pendidikan Ganesha Jurusan PGSD Vol. 2 No. 1.

Hamalik, Oemar. 2009. Proses Belajar Mengajar. Jakarta: Bumi Aksara.

Huda, M. 2013. Model-model Pengajaran dan Pembelajaran. Yogyakarta: Pustaka Pelajar.

2015. Cooperative Learning. Yogyakarta: Pustaka Pelajar.

Kosasih. 2014. Strategi Belajar dan Pembelajaran Implementasi Kurikulum 2013. Bandung: Yrama Widya.

Koyan, I Wayan. 2012. Statistik Pendidikan (Teknik Analisis Data Kuantitatif). Singaraja: Universitas Pendidikan Ganesha.

Mirnawati, Pramudiyanti Pramudiyanti, Berti Yolida. 2014. Pengaruh Model Examples Non Examples Terhadap Hasil Belajar Kognitif Dan Sikap Peduli Lingkungan. Jurnal Bioterdidik: Wahana Ekspresi Ilmiah Volume No 5.

Mulyasa, E. 2007. Menjadi Guru Profesional Menciptakan Pembelajaran Kreatif dan Menyenangkan. Bandung: Rosdakarya.

Sanjaya, Wina. 2006. Strategi Pembelajaran Berorientasi Standar Proses Pendidikan. Jakarta: Kencana Prenada Media Group.

าาาา 2014. Strategi Pembelajaran. Jakarta: Kencana Prenada Media Group.

Sudjana, Nana. 2009. Penilaian Hasil Proses Belajar Mengajar. Bandung: PT. Remaja Rosda Karya.

Sukardi. 2011. Metodelogi Penelitian Pendidikan. Jakarta: Bumi Aksara

Susanto, Ahmad. 2014. Pengembangan Pembelajaran IPS di Sekolah Dasar. Jakarta: Prenadamedia Group.

Setyosari, Punaji. 2015. Metode Penelitian Pendidikan \& Pengembangan. Jakarta: Kencana Prenada Media Group.

Sudijono, Anas. 2012. Pengantar Evaluasi Pendidikan. Jakarta: Raja Grafindo Persada.

Sugiyono. 2012. Metode Penelitian Kuantitatif Kualitatif dan R\&D. Bandung: Alfabeta.

2014. Metode Penelitian Kuantitatif Kualitatif dan R\&D. Bandung: Alfabeta.

Trianto. 2009. Mendesain Model Pembelajaran Inovatif Progresif, Konsep dan Implementasinya Pada Kurikulum Tingkat Satuan Pendidikan (KTSP). Surabaya: Kencana Perdana Media.

Wardika, Km, Md. Sulastri, Kt.Dibia. 2014. Pengaruh Model Examples Non Examples Terhadap Hasil Belajar Ipa Siswa Kls V Sd Di Gugus Iii Kecamatan Tampaksiring. Jurnal Mimbar PGSD Universitas Pendidikan Ganesha Jurusan PGSD , Vol: 2 No: 1. 